\title{
Domácí vzdělávání jako alternativní možnost ve světle virových omezení ${ }^{1}$ Stuart Nicolson
}

DOI: $10.32725 /$ cetv.2021.018

\begin{abstract}
Abstrakt: Uzavření škol v době virových omezení zavedených z důvodu pandemické situace způsobilo rozvrat ve vzdělávání u většiny dětí, s výjimkou dětí v domácím vzdělávání, jichž se tyto změny téměř nedotkly. Rodiče stojící před rozhodnutím, zda své děti vzdělávat doma, k tomu potřebují důvody i možnosti a v některých zemích již byl zaznamenán nárůst počtu rodičů, kteří se pro domácí vzdělávání rozhodli. Tento článek se stručně věnuje současnému vzdělávacímu kontextu: negativní zkušenosti většiny dětí, rodičů a učitelů v době omezení, obecné výhody a nevýhody domácího vzdělávání a současný stav domácího vzdělávání v České republice, kde je v posledních letech stabilně na značném vzestupu. Dále se věnuje řadě důvodů, zejména oněch aktuálních pro dnešní dobu, stejně jako způsobům, jak překonat překážky domácího vzdělávání. Navrhuje možná řešení, jak nabídnout podporu vzdělavatelům, včetně vytváření sítí, vyšší podpory ze strany dohlížejících škol, větší zaangažování akademiků v podpoře nových i zkušených vzdělavatelů a vyšší podíl vzdělávacích autorit při překonávání krátkodobých i dlouhodobých problémů.
\end{abstract}

Klíčová slova: lockdown, domácí vzdělávání, podpora, vzdělávání, subsidiarita, př́ležitost, stabilita vzdělávání, omezení

\section{Úvod}

Vzhledem k tomu, že školy byly ve školním roce 2020/21 zatím vnímány jako významná příčina šíření koronaviru, standardní formy výuky ve školách byly přerušovány a někdy zcela zrušeny. To působilo nepř́ijemnosti, a v některých případech dokonce i kompletní výpadek výuky a jistá míra narušení se stala „normální. Ztráta rutiny, struktury, kvalitních vstupů a př́istupů ke zdrojům způsobila mnoho praktických problémů. Na druhou stranu, dlouhodobější dopady na chování a př́istup k učení, kvalifikaci, a dokonce duševnímu zdraví či budoucí možnosti zaměstnání mohly způsobit, že se někteří začali ohlížet po alternativních vzdělávacích systémech či strukturách, jak je možné sledovat např́iklad ve Spojených státech, v Irsku a Velké Británii. ${ }^{2}$

2 Ve Spojených státech výrazně roste počet těch, kdo se obracejí k domácímu vzdělávání jako bezpečnější a stabilnější variantě, viz Arianna PROTHERO - Christina A. SAMUELS, Home Schooling Is Way Up With COVID-19. Will It Last?, ze dne 9. 11. 2020, dostupné 
V mnoha zemích jediné děti školního věku, kterých se narušení nedotklo, jsou ty, jež jsou zařazeny do tzv. individuálního vzdělávání, běžně označovaného jako domácí vzdělávání. Tato nejvíce subsidiární forma vzdělávání, jež se liší od onoho dnes nejběžněji zakoušeného „domácího vzdělávání“ $\mathrm{v}$ čase pandemických omezení, je téměř imunní vůči problémům v systému školství. To naznačuje, že pro rodiny, které tu možnost mají, stojí za to, zvážit výhody dlouhodobého, plánovaného domácího vzdělávání.

Tento článek ${ }^{3}$ se zaměří na dva klíčové faktory, které vedou rodiny k tomu, aby začaly s domácím vzděláváním - důvody a možnosti - zejména ve světle pandemických omezení. První část se opírá o aktuální zdroje v médiích pro zvážení dopadu přerušované výuky na učitele, žáky i rodiče. Ve srovnání s tím pak druhá část popisuje domácí vzdělávání a stručně pojednává o několika běžných výhradách vůči této formě vzdělávání. Třetí část ukazuje možnosti domácího vzdělávání v České republice, popisuje aktuální stav a vývoj domácího vzdělávání včetně právního rámce. Čtvrtá část se následně zaměřuje na širší důvody, proč zvolit domácí vzdělávání, které se týkají zejména stability a širších vzdělávacích možností, nabízených domácím vzděláváním bez ohledu na problémy ve společnosti. Pátý oddíl se konečně zamýšlí nad problémy a možnostmi domácího vzdělávání, a jak by zákonodárci, pedagogické autority i akademici mohli podpořit nové vzdělavatele a současně pomoci těm zkušenějším rozvíjet své vzdělávací schopnosti. Pokud takto začínající i zkušení vzdělavatelé dosáhnou podpory a možnosti rozvíjet efektivitu svého vzdělávání, více dětí získá možnost růstu díky domácímu vzdělávání, jenž se vyznačuje větší stabilitou zejména $\mathrm{v}$ časech narušené výuky a pro některé děti může být $\mathrm{z}$ různých důvodů vhodnější.

\section{Vzdělávání v omezení způsobuje omezení ve vzdělávání}

Restrikce spojené s pandemií viru a s tím spojená nejistota se výrazně podepsaly na vzdělávání většiny dětít navštěvujících školní instituce, jež jsou standardem v industrializovaných ekonomikách. Tři klíčové skupiny - učitelé, žáci a rodiče - byly poznamenány specifickými a navzájem propojenými způsoby. Je užitečné se na ně podívat ve dvou navzájem souvisejících vztazích: učitel-žák a rodič-žák. Tyto vzdělávací vztahy byly postaveny před zcela nové situace, nejčastěji negativního rázu. Na druhou stranu, tyto výzvy přinášejí šanci nalézat a rozvíjet nové způsoby. Zkušenost výuky a učení profesionálních učitelů a školních žáků byla významným způsobem poznamenána. ${ }^{5}$ Zatímco některé děti měly od svých učitelů zajištěný pravidelný přísun výukových materiálů domů prostřednictvím distanční výuky, jež se blížila normálnímu stavu alespoň co do ob-

na: https://www.edweek.org/policy-politics/home-schooling-is-way-up-with-covid-19-will-it-last/2020/11, citováno dne 1. 2.2021. Nejnovější data amerického Census Bureau (Statistický úřad) ukazují, že se domácí vzdělávání zdvojnásobilo na 11\% domácností: (c) Mike SCHNEIDER, Homeschooling doubled from pandemic's start to last fall, AP (on-line), ze dne 24. 3. 2021, dostupné na: https:// apnews.com/article/coronavirus-pandemic-census-2020-6ca21124cca741b9e6ec1c8256e1c921, citováno dne 11. 8. 2021. V Irsku vzrostl počet rodin, které podaly žádost o domácí vzdělávání v srpnu a záŕí 2020, pětinásobně oproti jiným rokům, viz Carl O’BRIEN, Covid-19 fears spark record increase in homeschooling, ze dne 27. 10. 2020, dostupné na: https://www.irishtimes.com/news/education/covid-19fears-spark-record-increase-in-homeschooling-1.4391659, citováno dne 1. 2. 2021. Navíc ve Velké Británii počet dětí, které odešly ze školního systému do domácího vzdělávání (tj. kromě těch, kteří začínají rovnou v domácím vzdělávání), narostl ve školním roce 2020/21 průměrně o $75 \%$ a v některých oblastech se více než ztrojnásobil. Viz @ Alix HATTENSTONE - Eleanor LAWRIE, Covid: Homeeducation numbers rise by $75 \%$, BBC News (on-line), ze dne 19. 7. 2021, dostupné na: https://www.bbc.com/news/education-57255380, citováno dne 21.7.2021.

3 Autor má více než 25leté zkušenosti s výukou v různých formách vzdělávání, včetně 15 let jako učitel na základní škole (děti ve věku 4-11 let) v Británii a nyní s domácím vzděláváním v České republice.

4 Srov. () John CARPENTER, Homeschooling is a great way to fight the coronavirus, ze dne 27. 8. 2020, dostupné na: https://members. classicalconversations.com/article/homeschooling-great-way-fight-coronavirus, citováno dne 1. 2. 2021.

5 Srov. ( Sara BUBB - Mari-Ana JONES, Learning from the COVID-19 home-schooling experience: Listening to pupils, parents/carers and teachers, ze dne 14. 9. 2020, dostupné na: https://journals.sagepub.com/doi/full/10.1177/1365480220958797, citováno dne 1.2.2021. 
sahu, ${ }^{6} \mathrm{když}$ už ne co do prostředí, $\mathrm{k}$ mnoha dětem se dostával pouze minimální nebo žádný výukový obsah. ${ }^{7}$ Toto selhání v zajištování stabilní kontinuity vzdělávacího obsahu může mít řadu př́ičin, od učitelů neposkytujících dostatečně kvalitní obsah, přses dostupnost až po jiné, domácí prríčiny. Učitelé, kteři alespoň s nějakou mírou efektivity poskytovali podporu svým žákům, se často pokoušeli napodobit standardní výuku pomocí elektronických komunikačních metod. Nabízeli žákům svých tříd dostupné on-line zdroje nebo vlastními silami připravené instrukce předávané emailem nebo formou videokonference. Zatímco používání zaznamenané informace (at už dokumenty nebo videa) je snazší a flexibilnější, živé video vstupy se více přibližují obvyklému vzdělávacímu paradigmatu učitele, který své žáky instruuje hromadně a do nějaké míry interaktivně. Problémy se však objevují pro obě skupiny. Pro děti, které se učí formou živého videa je nezbytné, aby byly on-line $\mathrm{v}$ přesně daný čas a $\mathrm{v}$ prríhodném domácím prostředí s minimem rušivých vlivů. Někdy se musí soustředit na malý obrázek učitele na obrazovce uprostřed dalších obrázků. Je náročné věnovat neustálou pozornost učiteli při menším počtu podnětů (tabule, vybavení, ukázkové materiály), jež by dětem dopomáhaly $\mathrm{k}$ soustředění, současně však domov může poskytovat značné množství rozptýlení. $Z$ psychologického hlediska může být rovněž pro děti z nejrůznějších důvodů náročné přizpůsobit se tomu, že učitel vstupuje do jejich domácího prostředí. Stávající zkušenosti budou jistě pro některé odborníky na vzdělávání širokým prostorem pro výzkum. Tato okolnost však může být problematická i na straně učitelů. Někteří mohou mít méně dovedností nebo jistoty s uživáním neobvyklého IT vybavení, nového softwaru apod., nebo nemusejí mít vhodné domácí prostředí pro tvorbu videa - at už živého, nebo záznamu. Učitelé jsou vyškoleni $\mathrm{k}$ tomu, aby uměli prezentovat a zprostředkovávat vzdělání $\mathrm{v}$ (do jisté míry) kontrolovaném prostředí školní trrídy, v něčem možná podobném divadelnímu jevišti. Nyní se však dostávají do situace podobné živému televiznímu vystoupení - je možné jej nahrávat, mohou k němu přihlížet také rodiče a neštastné chyby mohou být sdílené nebo dokonce zveřejněné: slavná videa zaznamenávající rodinná vyrušení ${ }^{8}$ ještě zvýrazňují možné problémy, takže tlak vždy „to udělat dobře“ je mnohem větší. Navíc je nezbytné vše efektivně plánovat a vyhodnocovat ve zcela novém vzdělávacím prostředí, které bude monitorováno nadřízenými, řediteli nebo dokonce inspekcí. Roli hraje také vědomí, že návrat k normální výuce bude velká výzva. A někteří učitelé musí současně poskytovat zázemí svým vlastním dětem, které se také učí doma.

Zatímco rodiče, kteří jsou také učiteli, mají alespoň porozumění a zkušenost, která jim pomůže se vzděláváním jejich vlastních dětí, mnohým dalším rodičům toto chybí. Vztah dítě-rodič není pro vzdělávání vždy nápomocný: některým rodičům chybí př́ílušné dovednosti, zkušenosti nebo možnosti. Struktura a podpora, jakým se dětem doma dostává, se liší např́klad podle osobního či rodinného plánování času, ${ }^{9}$ možnosti najít klidné místo $\mathrm{k}$ učení nebo dostatečného přístupu $\mathrm{k}$ počítači pro každé dítě. ${ }^{10}$ Svou roli hraje také stupeň vzdělání rodičůu, stejně tak jejich postoje vůči vzdělávání, vztahy se školou a především s učitelem či učiteli. Pro některé děti je nemožné

6 Srov. (C) Beatrice GOVE, Lockdown has been lonely and exhausting... Telling us our exams have been scrapped is the final straw says A-level student Beatrice Gove, ze dne 9. 1. 2021, dostupné na: https://www.dailymail.co.uk/debate/article-9129721/Telling-examsscrapped-final-straw-says-level-student-BEATRICE-GOVE.html, citováno dne 1. 2. 2021.

7 Srov. () Basit MAHMOOD, Parents in U.K. Left with One Laptop for Four Children, ze dne 30. 6. 2020, dostupné na: https://www. newsweek.com/coronavirus-schools-home-learning-u-k-education-1514390, citováno dne 1. 2. 2021.

8 Např́klad @ BBC News, Children interrupt BBC News interview - BBC News, ze dne 10. 3. 2017, dostupné na: https://www.youtube. com/watch?v=Mh4f9AYRCZY, citováno dne 1.2.2021.

9 Např́klad rodiče jednoho prvňáka se rozhodli odhlásit jej ze školy, dokud se nenavrátí normální stav: @ Sarah PARCAK, We Love Our Kid. That's Why We Said No to Remote Learning, dostupné na: https://time.com/5828836/coronavirus-homeschooling/, citováno dne 1.2. 2021

10 (C) Jane WAKEFIELD, Covid-19: The challenges of home-schooling, dostupné na: https://www.bbc.com/news/technology-55573803, citováno dne 1.2.2021. 
najít místo a počítač, kde by mohly mít přístup ke sdělením učitele, nemluvě o tom, že některé děti se nezapojovaly do vzdělávání ani v době před zavedením omezení.

Pro všechny tři skupiny školy poskytují jasný systém autority přímo zabudovaný do vzdělávacího systému. ${ }^{11} \mathrm{~V}$ domácím prostředí je však autorita jiná - někdy je méně jasná nebo zcela chybí takže některé děti se nemohou soustředit na učení $\mathrm{v}$ domácím prostředí, což vede $\mathrm{k}$ problémům mezi těmito třemi skupinami. Děti se také psychologicky vyrovnávají s autoritou, respektem, zodpovědností a vztahy s klíčovými dospělými jiným způsobem ve škole a jiným doma, takže nová přítomnost učitele doma může jistým způsobem zapříčinit určité problémy v sociálně-psychologickém vývoji dítěte.

Pokračování školního vzdělávání se tedy potýká s mnoha novými výzvami ve snaze vyvarovat se velkých otřesů, jež se zvětšují s délkou omezení. Na učitele, žáky i rodiče to těžce doléhá nevídanými způsoby. Přestože mnozí vykonali za dané situace to nejlepší, co mohli, důsledky budou pocitovány po mnoho let. Jedinou skupinou, která se nesetkala s těmito problémy, byly děti $\mathrm{v}$ domácím vzdělávání.

\section{Domácí vzdělávání a jeho obecné výhody a nevýhody}

Vzdělavatelů $\mathrm{v}$ domácím vzdělávání všeobecně se omezení dotkla pouze minimálně. Jedná se o menšinový, někdy neobvyklý způsob výuky dětí, přítomnýv různých kulturách a národech, kde je chápán různými způsoby, včetně negativních.

Byt domácí vzdělávání není vhodné pro všechny děti, obvykle je vnímáno jako pozitivní a bohatá zkušenost $\mathrm{s}$ mnoha potencionálními výhodami.

Ať už jej nazveme učení doma, domácí vyučování či neučení (angl. „unschooling“) atp., domácí vzdělávání se týká dětí, které jsou vzdělávány doma místo ve škole. Aniž by člověk byl romantik s růžovými brýlemi, je užitečné si uvědomit, že domácí vzdělávání je tou nejpůvodnější formou vzdělávání většiny dětí a zkušenost s navštěvováním školy s učitelem a dalšími žáky byla ve vzdálenější minulosti neobvyklá. $V$ oněch dobách bylo vzdělávání nad rámec toho, co vyžadovalo pokračování rodinného řemesla nebo obchodu, nejčastěji klasické liberální vzdělávání určené k tomu, aby osvobodilo jednotlivce a ten se stal tím nejlepším možným člověkem. Změna nastala ve spojitosti s osvícenstvím a průmyslovou revolucí. Oba tyto proudy byly silně umožněny a nabyly ve společnostech na síle právě tím, že všechny děti navštěvovaly školy, kde se jim dostávalo specifického obsahu vzdělání, aby byly připraveny stát se moderními občany a efektivními zdroji ekonomiky.

Dnes domácí vzdělávání nabízí velkou svobodu a mnoho možností. Umožňuje vybrat si jednu ze dvou vzdělávacích filozofií a jejich výstupů - udělat ze žáka lepšího člověka, nebo zvýšit jeho ekonomickou hodnotu. Je možné rozvíjet určité specializace nebo se zaměřit více prakticky např́iklad na pokračování zemědělské tradice atd. Jsou také různé možnosti s větší nebo menší mírou svobody ve vzdělávání dítěte, některé dokonce dovolují dítěti, aby si samo vybralo, co se bude učit, což se velice liší od naplňování stanovených osnov a modelu, kdy učitel-rodič vyučuje a vede žáka. Kontext výuky může být také prostoupen jazykem, kulturou nebo náboženským vyznáním rodiny či třeba místa. Podobně i časová struktura učení je variabilní s ohledem na denní dobu, týden nebo dokonce období. Domácí vzdělávání je organičtější a méně systematizované, lépe přizpůsobené rodině, přičemž se dítě rozvijí v obecně více pečujícím prostředí. Ačkoli různé země mají více či méně stanovená pravidla pro domácí vzdělávání, což může omezit jistou svobodu co do obsahu vzdělávání, struktura vzdělávání je svobodnější a určitá podpora nabízená rodinám

11 Viz John Taylor GATTO, Dumbing Us Down, Philadelphia (PA): New Society, 1992, s. 4-12. 
může být jen ku prospěchu.

Co do učení oplývá domácí výuka mnoha výhodami. Svoboda co a kdy učit je obzvláště nápomocná, když děti nezapadají do školních „norem“. Ne-průměrné dítě je silnější nebo slabší v různých dovednostech a předmětech, učí se lépe jiným stylem a někdy potřebuje víc podpory nebo více svobody, což lze při domácím vzdělávání zohlednit. Školy jsou také velice časově neefektivní. Děti v domácím vzdělávání mohou být vyučovány mnohem rychleji, což jim dává dostatek volného času na projekty, zahradničení, tělesné aktivity, specializaci atd. Rodiny se specifickými charakteristikami, at už jsou to rodiny bilingvní, hudebně nebo umělecky nadané apod., tak mohou dětem nabídnout mnohem víc. Samozřejmě nevýhodou je, že rodiče musí zorganizovat, co a jak se bude učit, připravit zdroje a vybavení, musí rovněž zajistit, že výuka bude přinejmenším dostačující. Nevýhodou, kterou však lze zároveň považovat za pozitivní výzvu, je skutečnost, že učitelé ve škole i rodiče vzdělavatelé jsou povoláni k tomu, aby vzdělávali děti v určitém specifickém prostředí, rodičům vzdělavatelům však na rozdíl od učitelů $\mathrm{k}$ tomu chybí průprava. Na druhou stranu však tito vzdělavatelé mají všeobecně silnou osobní motivaci rozvíjet své dovednosti během toho, jak se postupně stávají lepšími ve výuce svých dětí, což ne vždycky platí o učitelích. Může se stát, že rodič při domácí výuce neposkytuje uspokojivé vzdělání, podobně jako i učitel může selhat. At’ už dítě získá podporu, anebo ho rodina musí poslat do školy, mohlo to již způsobit škody na jeho vývoji; zlepšené vzdělávání (doma nebo ve škole) většinou vede $\mathrm{k}$ tomu, že dítě musí něco „dohánět“.

I v sociální oblasti skýtá domácí vzdělávání jisté výhody, zejména pokud se rozvíjí v malých skupinách či individuálně, kde se většina lidí cítí bezpečněji a společenské problémy jsou snadněji řešitelné. Ve škole není těžké identifikovat děti, které se v daném prostředí cítí nesvé. Některé děti dávají přednost učení se v menší skupině, čímž se vyhnou mnoha školním problémům, jako je tlak okolí na přizpůsobení se (módní oblečení a telefony, mluvit jako druzí atd.) a někdy také agresivita. Učitelé př́liš často věnují méně pozornosti dobrým žákům a spořádaným dětem a více se zabývají těmi, kteří dávají přednost zlobení před učením. Zatímco některé děti se už dokáží s různým skupinovým prostředím vypořádat a jiné se to naučí, jsou i takové děti, které počítají hodiny do konce vyučování - ne kvưli výuce, ale kvưli problémům v kolektivu. U některých dětí se tyto potíže navštěvováním školy neřeší, ale naopak zhoršují. Samozřejmě, ne každá rodina poskytuje dítěti zdravé prostředí, ale zevšeobecnění, že škola je po sociální stránce pro děti lepší než rodina, je nepřesné. ${ }^{12}$ Učit se ve vhodnějším prostředí, které odpovídá potřebám a preferencím dítěte, často znamená, že se z dětí v domácím vzdělávání stávají sebevědomější a ucelenější osobnosti.

V podobném duchu se nese i jiná typická námitka vưči domácímu vzdělávání ohledně socializace, která ř́ká, že děti v domácím vzdělávání se nestýkají s jinými dětmi a chybí jim společenská zkušenost, což později v životě vede k problémům. Předpokladem je, že škola je uspokojivým modelem socializace. Děti v domácím vzdělávání se však rozvíjejí ve více vertikálně strukturovaném společenském prostředí. Vyšší poměr dospělých k dětem než ve školní třídě lépe reprezentuje společnost a budoucí pracoviště. Pravidelný kontakt s lidmi jiných generací - včetně vzdělávacího (např́iklad členové širší rodiny ${ }^{13}$ ) - znamená, že děti mohou rozvíjet širší spektrum sociálních dovedností k širšímu spektru lidí a respekt vưči nim, např́klad díky pravidelným návštěvám obchodů, knihoven, muzeí, klubů apod. Na druhé straně děti ve škole mají mnohem více horizontálněji strukturované sociální zkušenosti. Pro některé je disciplína a pravidelnost školní do-

12 Viz např. John HOLT - Pat FARENGA, Teach Your Own, Cambridge (MA): Da Capo Press, 2003, s. 20-23, 31-39.

13 Srov. ( Robin Marantz HENIG, Grandparents Could Ease the Burden of Homeschooling, ze dne 10. 9. 2020, dostupné na: https://www. theatlantic.com/family/archive/2020/09/use-grandparents-help-homeschooling/616225/, citováno dne 1. 2. 2021. 
cházky vhodná ba dokonce kýžená: některé děti jsou skutečně rády ve škole. Naproti tomu však pro mnohé může být nevýhodou být celý den $\mathrm{v}$ restriktivním prostředí, $\mathrm{s}$ krátkými přestávkami strávenými na toaletách, chodbách a ve venkovních prostorách za jakýchkoliv povětrnostních nebo sociálních podmínek. Být veden $\mathrm{k}$ tomu, aby se dítě chovalo a interagovalo se stejnou skupinou lidí každý den po dobu deseti let, s občasnou změnou osoby vykonávající dohled, mohlo mít utilitární benefity při př́pravě pracovních sil do továren, ale k rozvoji sociálních zkušeností a dovedností dětí to přispívá minimálně. Pozitivní a snad př́ijemná výzva pro doma vzdělávající rodinu je rozvíjet sociální dovednosti, interakce a začlenění dětí do rodiny, sousedství a širšího okolí. Doma vzdělávané dítě má možnost přicházet do styku s širokou škálou lidí nejrůznějšího věku, schopností, povolání a pozic: rodina mu musí tyto př́ležitosti poskytnout.

Může se stát, že domácí školák není dostatečně vyučován nebo mu není poskytnut dostatek př́iležitostí naučit se sociálním dovednostem. $\mathrm{V}$ tomto může spočívat neúspěch a selhání systému domácího vzdělávání. Ovšem obdobně jsou i školy, které neposkytují vhodné prostředí pro učení a společenský rozvoj, a to $\mathrm{v}$ mnohem větší míre. Vhodné monitorování $\mathrm{v}$ obou prostředích může problémy odhalit. Je důležité, aby dětští lékaři, učitelé, širší rodina a místní komunita byli schopni zasáhnout, stejně jako tomu je u problémových škol a selhávajících učitelů. Proto když se někde objeví selhání $\mathrm{v}$ rodině $\mathrm{s}$ domácím vzděláváním, není to chyba samotného domácího vzdělávání jako takového, ale důsledek konkrétních prríčin: rodina, jež selhává v povinné péči, a sociální/ právní systém, který neumí efektivně odhalovat problémy a činit vhodné zásahy.

Domácí vzdělávání je tedy reálnou možností pro některé rodiny - rodiče a děti - kteří hledají alternativu ke společenské normě školního systému. ${ }^{14}$ Domácí vzdělávání nabízí mnoho výhod, a to více, než je zde v krátkosti zmíněno, těm, kdo přijmou tuto - často naplňující a hodnotnou - výzvu, zejména v oblasti vzdělávání a sociálního rozvoje. Potíže lze často překonat odhodláním a vytrvalostí. $V$ př́padech selhávání domácího vzdělávání, byt̉ hlavní odpovědnost oprávněně spočívá na rodičích jako primárních opatrovnících, nesou jistou odpovědnost patřičným způsobem zasáhnout i lidé v okolí a stát.

\section{Domácí vzdělávání v České republice}

Domácí vzdělávání je nejvíce subsidiární metoda vzdělávání, která může mít mnoho forem - což je současně výhodou i nevýhodou. Je mnohem flexibilnější, více v souladu se životem a zkušenostmi rodiny a dítěti nabízí jisté vzdělávací výhody. Mủže však být také náročné na organizaci, je silně závislé na zkušenostech a situaci rodiny a překonat jistá omezení může být výzva. Některé země vyžadují dohled nad touto formou vzdělávání, některé mohou také nabízet podporu. Pravidla se v různých krajinách liší. Zatímco ve Velké Británii je v tomto ohledu velká volnost, ${ }^{15}$ v jednotlivých státech USA se míra volnosti liší, ${ }^{16}$ jiné země nastavují různé limity. ${ }^{17}$ V některých

14 Několik příběhů o tom, jak lidé začali s domácím vzděláváním kvůli pandemickým omezením, je představeno v: @ Lucy BALLINGER - Alex JENNINGS, Covid and home schooling: Children "flourishing" as numbers rise, BBC News (on-line), ze dne 25. 11. 2020, dostupné na: https://www.bbc.com/news/uk-wales-55063094, citováno dne 21. 7. 2021.

15 ๑) Nick MORRISON, Fears Children Going “Off-Grid” As Homeschooling Up By 700 \%, ze dne 6. 3. 2020, dostupné na: https://www. forbes.com/sites/nickmorrison/2020/03/06/fears-children-going-off-grid-as-homeschooling-up-by-700/2 citováno dne 1. 2. 2021. Ve Velké Británii není žádný požadavek registrace pro děti v domácím vzdělávání (i když v současnosti se plánuje změna) - odhadovaný počet v roce 2018 byl asi 60 000. Nad domácími školáky je vykonáván dohled pouze v případě, kdy někdo nahlásí, že žádná výuka neprobíhá.

16 Data jsou k dispozici na ( $\odot$ Cato Institute, Freedom in the 50 States: Get the Data, dostupné na: https://www.freedominthe50states.org/ data, citováno dne 26. 1. 2021, v tabulce pod záložkou „Personal“. Počet dětí v domácím vzdělávání v USA byl v roce 2016 odhadován různě od 1,5 do více než 2 miliónů, srov. @ Brian D. Ray, Homeschooling Growing: Multiple Data Points Show Increase 2012 to 2016 and Later, dostupné na: https://www.nheri.org/homeschool-population-size-growing/, citováno dne 26. 1. 2021.

17 Obecný přehled ukazuje Wikipedie, detaily však mohou být nepřesné: (C) Wikipedia, Homeschooling international status and statistics, dostupné na: https://en.wikipedia.org/wiki/Homeschooling_international_status_and_statistics, citováno dne 27. 1.2021. 
zemích může být domácí vzdělávání dokonce ilegální, jako například v Německu. V České republice je domácí vzdělávání povolené ve všech ročnících povinné školní docházky, od posledního ročníku mateřské školy až do konce základní školy (5-15 let věku), i když s konkrétními požadavky, což znamená, že „přísně regulovány“: 18 jsou stanovené požadavky na stupeň vzdělání vzdělavatele (rodič nebo placený učitel), ${ }^{19}$ je vyžadován dohled školy, přezkoušení dvakrát ročně a souhlas pedagogického psychologa. ${ }^{20}$ Ve školním roce 2019/2020 bylo v České republice přibližně 3900 dětí v domácím vzdělávání, z čehož ZŠ Březová dohlíží na $970 .{ }^{21}$ Domácí vzdělávání má v České republice již svou historii: pro některé pokračovala i po zavedení povinné školní docházky v roce 1774, regulace standardů výuky byla zavedena v roce $1905 .{ }^{22}$ Domácí vzdělávání bylo zakázáno v roce 1938 německými autoritami, ${ }^{23}$ není však zcela jasné, zda to platilo i v českých zemích. Domácí vzdělávání zakazoval také komunistický školský zákon z roku $1948 .{ }^{24}$

Domácí vzdělávání v České republice, označované jako „individuální vzdělávání, bylo zákonem povoleno pro děti na prvním stupni ZŠ (6-11 roků) od roku 2005, po přísně regulované sedmileté zkušební době. ${ }^{25}$ Podobný experiment začal v roce $2007^{26}$ pro děti ve zbylých ročnících povinné školní docházky (druhý stupeň ZŠ, 12-15 roků), což vyústilo v plné uzákonění v roce $2016 .{ }^{27}$ V roce 2006 bylo do programu zapojeno 360 dětí, v roce 2012 byl tento počet téměř dvojnásobný. Od roku 2012 počet každoročně stoupal na téměř 1,5 násobek $^{28}$ až k dnešnímu počtu. Z necelého jednoho milionu školou povinných dětí ${ }^{29}$ se tedy domácí vzdělávání vyskytuje s frekvencí 0,4 \%, tj. čtyři na tisíc. S dalším rozvojem, kdy více lidí šírí pozitivní informace o této možnosti, popularita domácího vzdělávání pravděpodobně poroste, možná ještě rychleji v důsledku současných společenských omezení. To znamená, že požadavky a podpora domácího vzdělávání může vyžadovat přehodnocení a další podporu ze strany vzdělávacích autorit.

Škola v Březové poskytuje dohled a hodnocení u přribližně čtvrtiny dětí v individuálním vzdělávání v zemi, přestože se nachází blízko hranic se Slovenskem. Při pouhé více než stovce žáků navštěvujících školu „normálně“ tvoří většinu zapsaných žáků školáci v domácím vzdělávání, které škola hodnotí na vícero místech v republice dvakrát ročně. V roce 2016 vláda doporučila vzdělavatelům vyhledávat podporu ze strany škol: „Individuálně vzdělávaní žáci se mohou na základě dohody se školou do výuky svého ročníku zapojovat i prostřednictvím e-learningu, her nebo interaktivních vzdělávacích programů, což je výhodné i pro žáky s poruchami učení. “30 Škola

18 Jak bylo popsáno tamtéž, v oddílu Czech Republic.

19 Pro první stupeň základní školy (6-11 let) je zapotřebí maturita, pro druhý stupeň (12-15 let) je vyžadováno vysokoškolské vzdělání.

20 ๑ Školský zákon 561/2004 Sb. \$41, dostupné na https://www.msmt.cz/uploads/skolsky_zakon.pdf, citováno dne 1.2.2021, \$41.

21 Data z ledna 2021. Srov. @ Školy Březová, O nás, http://www.skolybrezova.eu/o-nas/o-nas, citováno dne 26. 1. 2021.

(C) Jiř́ NĚMEČEK, Home and Community Schooling in the Czech Republic, United Kingdom and the USA. Brno, 2017. Diplomová práce. Masarykova univerzita. Pedagogická fakulta. Katedra anglického jazyka a literatury. Vedoucí práce Ailsa Marion Randall, M.A., dostupné na: https://is.muni.cz/th/h1s9l/Home_and_Community_Schooling_in_the_Czech_Republic_United_Kingdom_and_the_ USA.pdf, citováno dne 26. 1. 2021, s. 40-41.

23 Tamtéž, s. 38.

24 Tamtéž, s. 41.

25 () Yvona KOSTELECKÁ, Home education in the post-communist countries: Case study of the Czech Republic, International Electronic Journal of Elementary Education 1/2010, dostupné na https://web.archive.org/web/20111021050558/http://www.iejee. com/3_1_2010/29_44.pdf, citováno dne 1.2.2021, s.32-34.

26 (C) Ministry of Education, Youth and Sports, Proclamation of experimental period, ze dne 23. 5. 2007, dostupné na: http://www.msmt.cz/ file/9571_1_1/, citováno dne 30.1.2021.

27 (C) Czech School Inspectorate, Thematic Report, 2016, dostupné na http://www.atre.cz/aktuality/stahni/id/581, citováno dne 1. 2. 2021 , s. 3.

28 Přibližná čísla dle grafu ve @ Ludvík ZIMČÍK, Udělejme si školu doma aneb: Jak na domácí vzdělávání?, blog z 10. října 2017, dostupné na: http://www.skolybrezova.eu/o-nas/rediteluv-blog/491-udelejme-si-skolu-doma-aneb-jak-na-domaci-vzdelavani, citováno dne 20. 1. 2021; viz také @ Martin Mana, Jak se mění počty žáků na základních školách, ze dne 30. září 2020, dostupné na: https://www. statistikaamy.cz/2020/09/30/jak-se-meni-pocty-zaku-na-zakladnich-skolach, citováno dne 20. 1. 2021. 
v Březové nabízí řadu kurzů a dalších zdrojů, jež jsou k dispozici pro eventuální domácí použití. Tyto jsou z mnoha důvodů pro rodiče obzvláště užitečné. Lze doufat, že se bude rozvíjet další spolupráce mezi vzdělavateli a školami, možná i s přispěním vzdělávacích autorit, což by mohlo vést $\mathrm{k}$ novým formám vzdělávání.

Za téměř 40 let $\mathrm{v}$ učitelské profesi se ředitel Základní školy Březová, Ludvík Zimčík, setkával v Čechách s pěti základními typy vzdělavatelů v domácím vzdělávání, v nichž se zrcadlí výše zmiňovaná témata: děti ve zvláštním tréninkovém režimu během školy - například atleti; děti trpící šikanou; děti se zdravotními potížemi nebo různými vzdělávacími potřebami; děti rodičů $s$ jasnými hodnotami, které chtějí předávat dál (například náboženské nebo př́rodně orientované) a děti těch, kdo jsou nespokojeni s mainstreamovým školstvím a hledají jiný styl výuky. ${ }^{31}$ Potvrzuje také to, že se nikdy nesetkal se žádnými extrémisty, naopak shledal, že rodiče mívají závažné důvody pro volbu této formy vzdělávání a že o své děti řádně pečují. ${ }^{32}$

Domácí vzdělávání má v Česku narůstající trend. Legislativa v posledních desetiletích jej postupně více umožňuje, přičemž však vyžaduje dodržování jistých standardů. Otázkou je, zda tento trend bude ve stávající situaci ve spojitosti se současnými virovými omezeními dále narůstat, jak to předpovídá Christopher Lubienski v Americe: „Někteří lidé možná kvůli pandemii [...] přišli beztak o práci, takže vzdělávání doma se stává mnohem více možným, ' ř́ká Lubienski. Také se domnívá, že domácí vzdělávání se stane více mainstreamovým a společensky přijatelným, když nyní tolik lidí získává zkušenost se vzděláváním svých dětí z domova - at už je to skrze klasické domácí školy nebo při dohledu nad vzděláváním svých dětí na dálku. “33

Domácí vzdělávání v Čechách je tedy regulováno, počty jsou malé, ale významně rostou. Důvody pro domácí vzdělávání jsou různé, budeme o nich pojednávat níže. Následně zaměříme pozornost také na překážky, jež je zapotřebí překonat, zejména v českém kontextu.

\section{Důvody pro domácí vzdělávání, zejména ve světle omezení}

Omezení spojená s pandemií koronaviru způsobila dětem všech úrovní, věků a schopností vážné škody. Výuka dětí v domácím vzdělávání však byla téměř nezasažena, protože je postavena na základě domova, jenž je v čase společenských problémů stabilnější a robustnější než cokoliv jiného. Rodiny se mohou rozhodovat pro domácí vzdělávání $z$ různých příčin: některé jsou dnes jasnější $\mathrm{v}$ souvislosti s vynuceným domácím vzděláváním, tyto důvody mohu rodiče a děti vést $\mathrm{k}$ tomu, že se pro domácí vzdělávání rozhodnou trvale i poté, co omezení pozbydou platnosti, jako se tomu stalo např́klad v Americe. ${ }^{34}$

Tato poněkud extrémní situace byla nepředvídaná, a tudíž žádná země na ní nebyla dostatečně připravena. Rodiče jsou znepokojeni délkou současných protipandemických omezení a stejně tak možností restrikcí v budoucnu, které by z různých důvodů mohly nastat. Mnozí dnes vkládají své naděje do vakcín a kolektivní imunity, žádná záruka návratu do normálního stavu však není, zejména vzhledem $\mathrm{k}$ novým mutacím viru. Tuto nejistotu ještě přiživují média, jež mohou zveličovat nejrůznější příběhy, aby navýšily prodeje a počty kliknutí na on-line články, čímž vzbuzují

Individual Education Students in Basic School, ze dne 11. 10. 2016, dostupné na https://www.msmt.cz/file/46873_1_1/, citováno dne 1. 2. 2021, s. 9 .

31 ZIMČÍK, Udělejme si školu..

32 Tamtéž.

33 (C) PROTHERO - SAMUELS, Home Schooling Is...

34 Několik takových situací je popsáno v @ David CRARY, Sparked by pandemic fallout, homeschooling surges across US, AP (on-line), ze dne 26. 7. 2021, dostupné na: https://apnews.com/article/health-religion-coronavirus-pandemic-race-and-ethnicity-5385d17b9f91591f 4baae71bafb71f0c, citováno dne 11.8.2021. 
jak naději, tak zoufalství a přispívají k nestabilitě. Pro některé znepokojené rodiče může být domácí vzdělávání řešením některých $\mathrm{z}$ těchto problémů.

I jiné faktory mohou potenciálně narušovat vzdělávání dětí a způsobovat problémy, at’ už jsou specifické pro Českou republiku, či platné i pro další země. Některé jsou obecnějšího charakteru, jiné jsou osobní, mohou mít ráz dočasný nebo trvalý: nepříznivé počasí, potíže s dopravou - at už veřejnou nebo soukromou, styl vzdělávání, školní osnovy, neshody s místními školami, náboženské přesvědčení, životní styl, tlak spolužáků nebo šikana, děti se zvláštními potřebami nebo mimořádně nadané, nebo jiné zvláštnosti jako např́klad jazyk. Někteří rodiče mohou na tyto důvody reagovat právě tím, že budou hledat větší stabilitu ve vzdělávání svých dětí.

Mezinárodní nebo místní problémy mohou například zpơsobit potíže s dopravou nebo financováním, včetně konfliktů týkajících se zemí produkujících ropu, globální finanční nestabilita, nebo budoucí extrémní výkyvy počasí, před nimiž někteří vědci varují, dále příliš vysoká cena technologií elektromobilů atd. Seznam možných problémů je dlouhý a většinou signalizuje nejistotu a nestabilitu. Už samotný fakt, že mutace viru ve východní Asii může mít takový globální dopad, poukazuje na výhody vyšší subsidiarity, snahy o setrvávání v místě a využívání místních zdrojů: v kontextu vzdělávání to znamená učit se v rámci vlastní domácnosti.

Lidé si dnes také více uvědomují rozdíly mezi různými styly vzdělávání. Styl klasické třídy byl efektivní pro potřeby industrializované společnosti a v posledních desetiletích se v mnohém zlepšil. Stále však je postaven na principu třídy ,jedna velikost pro všechny“, jenž je velice neefektivní vzhledem k času i k potřebám jednotlivců nebo malých skupin. Organizovaný vzdělavatel může doma poskytnout celodenní penzum výuky za méně než dopoledne, navíc s osobním přístupem a náplní, která odpovídá zájmům a potřebám dítěte, což ponechává víc času na projekty, zahradničení, uměleckou činnost nebo výlet (byt momentálně jen omezeně). Dítě, které je frustrované nebo se nezapojuje, může trpět těmito problémy $\mathrm{v}$ domácím prostředí výrazně méně a chování zpravidla nepředstavuje potíže, nebot vzdělávání je více přirozené a integrované. $\mathrm{V}$ době viru je pak rekreace v parku nebo na zahradě jistě lepší, než čas strávený v roušce a s dalšími omezeními v přísně oddělených skupinkách nebo individuálně na hřišti nebo na chodbě. To znamená, že domácí vzdělávání se svou organickou strukturou je výrazně vhodnější pro intelektuální i osobnostní rozvoj toho kterého dítěte. Obsah školních osnov může být některými rodiči také považován za problematický. Některé děti jsou ve škole vystaveny tématům, která by jim jejich rodiče rádi představili později nebo jiným způsobem, at už se jedná o témata jako násilí, otázky sexuality, politické otázky a názory, společenská témata apod. Příkladem může být četba knih pro malé děti s postmoderními genderovými stereotypy ${ }^{35}$ a časté téma dětí, které neustále přechytračují zaostalé dospělé. Styl osnov také nemusí být vždy nápomocný: některým dětem může vyhovovat tzv. spirální metoda, kde se například jeden týden $\mathrm{v}$ matematice probírá sčítání, a další týden je pak pozornost věnována tvarům a tak dále, zatímco jiné děti se učí efektivněji jedné disciplíně i měsíc a déle. Podobně, pokud dítě není připraveno pro nějakou konkrétní dovednost, je snazší ji doma odložit na později, což škola nemůže udělat. Domácí vzdělávání dává větší možnost flexibility, co se týče struktury, stylu a obsahu, dokáže se přizpůsobit preferencím žáka i rodiny. Rodiče mohou nyní více vnímat problémy v tom, co se jejich děti učí, a snažit se převzít nad tím kontrolu skrze domácí vzdělávání.

Místní školy mohou také hrát jistou roli. Vztahy mezi rodiči, školami a učiteli se mohou různit. Příčiny mohou být v konkrétních osobnostech nebo v nabízeném stylu výuky. Někteří učitelé rodiče vítají, jiní staví zdi; někteří rodiče se chtějí zapojovat a spolupracovat, někteří se do spoluprá-

35 Například série Oxford Reading Tree pro nové a začínající čtenáře: otec je často představovaný jako nešikovný a bláznivý, zatímco jeho dcera se na něj někdy zcela jasně dívá spatra. 
ce nehrnou a někteří se nechtějí zapojit vưbec. Problémy mohou vyvolávat také školní pravidla narůstajícím problémem v některých zemích, jako např. v USA, jsou genderově neutrální toalety, kde všichni používají tatáž zařízení nebo si mohou volně vybírat, kterou z oddělených toalet chtějí použít. Cílem těchto uspořádání je, aby si malá skupinka připadala příjemněji, zatímco pohodlí většiny je upozaděno, nemluvě o její bezpečnosti. $V$ těchto omezujících dobách mohou mít rodiče potíže se vzdělávacími autoritami, vedením školy nebo i každý den s učiteli, včetně těch, kteří vyžadují, aby jejich harmonogram všichni dodržovali i bez ohledu na to, do jaké míry to narušuje život domácnosti. Nedostatek kvalitních zdrojů nebo vyučování může způsobit, že rodiče začnou tyto mezery vyplňovat svými silami - což může vyústit až k tomu, že se domácí vzdělávání začne jevit jako myslitelné řešení.

Další oblastí, která je někdy problematická, je otázka náboženství ve vzdělávání, respektive jeho absence $\mathrm{v}$ dnešních převážně sekulárně humanistických společnostech. V některých zemích jsou církevní školy běžné nebo alespoň do nějaké míry dostupné a mohou být efektivní při rozvoji náboženského porozumění a zkušenosti u dětí, ale u mnoha tomu tak není - bývá to jen nálepka neodpovídající inzerovanému náboženskému obsahu. V některých zemích školy založené na víře chybí, nebo nabízejí v povinné výuce pouze sekulární vzdělání, jako tomu je v České republice. Někdy může místní škola nabízet náboženský obsah a/nebo kontext, jenž se liší od přesvědčení rodiny, někdy dokonce i v rámci téhož náboženství či denominace. Občas se rodiče musí vyrovnávat s tím, že jejich děti jsou ve škole vystavené tématům nebo naukám, které jsou proti jejich přesvědčení, u dítěte to pak může vést $\mathrm{k}$ dichotomii důvěry a autority. Současná omezení ve větší míře umožnila rodinám vzdělávat své děti v kontextu víry a s obsahem více $\mathrm{v}$ souladu s přesvědčením rodiny. Pro některé může myšlenka návratu dětí do problematického, ba přímo toxického vzdělávacího prostř̌edí vést $\mathrm{k}$ trvalému domácímu vzdělávání.

Domácí škola umožňuje poskytovat vzdělávací obsah bohatý na víru a na nauku rodinného přesvědčení. Sekulární školní systém do jisté míry vede k tomu, že děti se intelektuálně rozvíjejí odděleně od své víry, což vede k jistému stupni nesouladu mezi světským učením a životem víry. Namísto toho mohou být děti v domácím vzdělávání vyučovány podle obecných osnov, leč v souladu s domácím přesvědčením, a tak se intelektuálně rozvíjet i ve své víře. Jako aktuální příklad může posloužit skutečnost, že většina hlavních vakcín proti onemocnění covid-19 má do nějaké míry svůj původ v tkáních potracených plodů, ${ }^{36}$ což je pro mnoho nábožensky založených lidí závažný etický problém. Toto může být rozsáhlá oblast pro vyučování etiky pro starší děti, kde se mohou kupř́íkladu naučit, že katolická církev je proti takovému postupu. ${ }^{37}$ Církev však také poukazuje na to, že ačkoliv vakcinace „musí být dobrovolná", 38 je z etického hlediska doporučeníhodné, aby se věřící nechali očkovat neetickou vakcínou, pokud není k dispozici jiná, etická, nebo aby „vykonali vše, co je v jejich silách, aby se vyvarovali jinými profylaktickými prostředky a náležitým chováním, “"39 a měli by jasně dát najevo svůj nesouhlas s takovými neetickými zdroji. ${ }^{40}$

36 C Children of God for Life, Covid-19 Vaccines and Treatments in Development, ze dne 28. 12. 2020, dostupné na: https://cogforlife.org/ wp-content/uploads/CovidCompareMoralImmoral.pdf, citováno dne 30. 1. 2021.

37 (c) Pontifical Academy for Life, Moral Reflections on Vaccines Prepared from Cells Derived from Aborted Human Foetuses, dopis datovaný dne 9. 6. 2005, dostupné na: https://cogforlife.org/wp-content/uploads/2012/04/vaticanresponse1.pdf, citováno dne 30.1. 2021, shrnuto na s. 7-8.

38 (c) Luis LADRIA - Giacomo MORANDI, Note on the morality of using some anti-Covid-19 vaccines, Congregation for the Doctrine of the Faith, ze dne 21. 12. 2020, dostupné na: http://www.vatican.va/roman_curia/congregations/cfaith/documents/rc_con_cfaith_ doc_20201221_nota-vaccini-anticovid_en.html, citováno dne 30.1.2021, s. 5.

39 Tedy pravděpodobně používáním roušek a dodržováním vzdáleností a odstupu. Tamtéž.

40 Srov. (C) Stacy Trasancos, How to Object to an Abortion-Tainted COVID-19 Vaccine, National Catholic Register, ze dne 21. 12. 2020, dostupné na: https://www.ncregister.com/commentaries/how-to-object-to-an-abortion-tainted-covid-19-vaccine, citováno dne 30. 1. 2021; srov. také Pontifical Academy for Life, Moral Reflections..., s. 7. 
Podobné otázky mohou vyvstávat v oblasti životního stylu, rodinných tradičních preferencí. Kupříkladu plně soběstačná rodina bude proti užívání dopravy do školy. Technologicky zaměření rodiče by mohli dávat přednost tomu, aby se jejich dítě učilo programovat místo (o několik let později) používat vyhledávače. Přesvědčení a preference rodin jsou velice různé a mainstreamové školství nemůže efektivně vzdělávat všechny děti v čím dál tím více fragmentovaném světě, kde zájmy a schopnosti lidí jsou méně konvenční. V oblasti filozofie vzdělávání mohou někteří rodiče dávat přednost tradičnímu cíli rozvoje individua do plnosti před výchovou k tomu, aby se stal efektivním zdrojem pro společnost a více světský úspěch. Onen první cíl je lépe naplnitelný skrze klasické liberální vzdělávání nebo některou z jeho moderních alternativ. Tomu druhému slouží industriální systém výuky skupin dětí a jejich socializace ve velkých skupinách vrstevníků, což umožňuje vytvářet budoucí dělníky - to se ale pravděpodobně více hodí do minulosti. Dnes zakoušená omezení mohou někoho vést k tomu, aby se znovu zamýšlel nad cílem vzdělávání dětí. Školním systém umožňuje tlak vrstevníků a šikanu. Některé děti se cítí ve velkém kolektivu nepohodlně nebo i hưř̀e. Trpí v něm at’ už z osobních důvodů - nedostatek sebedůvěry, sociálních dovedností nebo vhodných potenciálních kamarádů - nebo kvůli znakům nepřijetí ze strany skupiny, např. označování někoho za nesympatického, nemoderního, jiného atd. Zatímco některé děti se společensky rozvíjejí, když jsou vhozeny do společenské směsice, jiné se v ní v lepším případě cítí nepř́ijemně a $v$ horším případě je to pro ně utrpení. Skupina dětí má tendenci následovat nejsilnější osobnosti, což často postupně vede $\mathrm{k}$ nejhoršímu společnému jmenovateli. Outsideři se musí naučit přizpůsobit se, jinak nejsou přijati. Pro některé děti je proto škola sociálně problematická, a poté co štastně zůstaly doma a zjistily, že je zde učení př́jemnější, myšlenka na návrat do školy bude problémem. To pochopitelně může být rozhodujícím faktorem pro některé rodiče, aby se rozhodli pro trvalé domácí vzdělávání.

Pro některé rodiče, kteří své děti vzdělávají doma, jejich dítě nemusí zapadat do studijních kategorií, jaké vyhovují generalizované výuce. Byt’ se učitelé snaží hodiny odstupňovat, potřeby některých dětí budou jen zrrídka naplněné. Děti s pomalejším rozvojem učení mohou mít doma vhodnější výuku, aniž by si připadaly odlišné nebo prožívaly pocity selhání. Podobně i ti, kteří jsou v učení o několik ročníků napřed, nejsou vedeni k tomu, aby tlumili svou touhu po učení, aby tak snáze zapadli do davu, nebo se nudili, což může vést ke špatnému chování. V některých školách si akademicky nadané dítě musí vybírat mezi úspěchem nebo přijetím, na druhou stranu mezi úspěšnými vrstevníky pomalejši žák zápasí o přijetí nebo se z něj stává třídní šašek. Pro tyto děti a jejich rodiče mohly pandemické restrikce přinést zcela novou zkušenost: pracovat $s$ tím, co dovedou, a s lepší podporou se rozvíjet.

Konečně mezi doma vzdělávanými dětmi najdeme i takové, kterým prospívají určité specifické faktory, at už je to muzikální prostředí, pokud jsou rodiče muzikanti, praktická výchova rozvíjená vedle akademického vzdělávání, bilingvní děti, jež se učí v obou jazycích, nebo dítě, jehož rodiče jej mohou učit mnohem efektivněji než různě dovední profesionálové mající v péči další tři desítky dětí, které než dostatečně poznají, tak je běžící pás v září přesune $\mathrm{k}$ další várce. Podle učení katolické církve, rodiče jsou „první a hlavní vychovatelé“. ${ }^{41}$ Bez ohledu na své schopnosti nejlépe znají své dítě, nejvíce o něj pečují a milují ho, leží jim na srdci jeho dobro. Byt je to do jisté míry ideál, tento ideál je posílen domácím vzděláváním, je-li prováděno z těch správných pohnutek, které si v nynější době mohou někteří rodiče snáz vyjasnit.

41 C Druhý vatikánský koncil, Gravissimum Educationis, ze dne 28. 10. 1965, dostupné na http://www.vatican.va/archive/hist_councils/ii_ vatican_council/documents/vat-ii_decl_19651028_gravissimum-educationis_en.html, citováno dne 30. 1. 2021, čl. 3. Viz také Papežská rada Justitia et pax, Compendium of the Social Doctrine of the Church, dostupné na: http://www.vatican.va/roman_curia/pontifical_ councils/justpeace/documents/rc_pc_justpeace_doc_20060526_compendio-dott-soc_en.html, citováno dne 30.1.2021, s. $238-243$. 
Domácí vzdělávání lze samozřejmě realizovat i z nesprávných důvodů, je to však spíše výjimka. Je určitým klišé, že domácí školáci nejsou normální, nezapadají nebo dokonce jsou extrémisti. Byt to poslední může být pravda pro početně velmi omezenou menšinu, většinou slyšíme jen o extrémech, a ne o běžné většině, která nevyvolává pomluvy. Výše zmíněný ředitel školy Březová se ještě nikdy nesetkal s rodinou, u níž by důvodem pro domácí vzdělávání byl nějaký extrémismus. Základní volbou pro rodiče musí být běžný školní systém, jelikož ten poskytuje bezpečnou záchytnou sít co do požadavků. Rozhodnutí vzdělávat doma nesmí být činěno lehkovážně. Je však mnoho důvodů pro domácí vzdělávání dětí tam, kde to je možné. A kde děti mohou skutečně profitovat z domácí školy, je na odpovědnosti rodičů, aby pečlivě posoudili, je-li to pro ně uskutečnitelné. $V$ současnosti děti i rodiče mají možnost si domácí vzdělávání vyzkoušet, byt zpravidla bez plné odpovědnosti za strukturu, zdroje a zavádění vzdělávání do života domácnosti. To znamená, že někteří rodiče ${ }^{42}$ dnes mají jasné důvody pro domácí vzdělávání jako jakýsi prvotní stimul, je však možné, že nemají možnost nebo př́ležitost si tento způsob vzdělávání vybrat.

\section{Přijetí výzvy, s podporou}

Byt je mnoho důvodů pro přechod na domácí vzdělávání, rodiče, kteří se o to zajímají, mohou mít pocit, že $\mathrm{k}$ tomu není vhodná př́ležitost, když jej různé tlaky během života mohou zmařit. Ačkoli je zapotřebí učinit určité oběti, $\mathrm{k}$ dispozici je i jistá forma podpory, ovšem bylo by možné udělat i mnohem více pro rodiče, kteří začínají své dítě vzdělávat doma. V České republice je někdy možné nalézat řešení $\mathrm{v}$ rámci domácnosti nebo rodiny, vhodná podpora by mohla přijít skrze účast zákonodárců, vzdělávacích autorit a akademických expertů.

První překážka pro domácí vzdělávání je nejčastěji čas. V postmoderní společnosti jsou oba rodiče $\mathrm{v}$ tradiční rodinné struktuře vedeni $\mathrm{k}$ tomu, aby měli zaměstnání - obvykle na plný úvazek. V souladu s plnou školní výukou byl tento ekonomicko-sociální vzorec standardním modelem v Českých zemích od poválečné doby, čímž znehodnocoval tradiční obraz rodiče, který zůstává doma. Pro rodiče samoživitele je domácí vzdělávání mimořádně velkou výzvou, ale přesto je v některých případech uskutečnitelné. ${ }^{43}$ Zatímco v některých kulturách byla flexibilita rozvíjena už po několik desetiletí - práce na částečný úvazek, živnosti, sdílená pracovní místa, pružná pracovní doba a práce $\mathrm{z}$ domova - Česká republika je v tomto ohledu dosud silně neflexibilní a pobyt na pracovišti na plný úvazek je stále normou.

Avšak i v tomto ohledu již začalo docházet k změnám: nedávná novela zákoníku práce uzákonila sdílená pracovní místa. ${ }^{44}$ I pandemická omezení snad ukázala, že flexibilnější přístup je uskutečnitelný - flexibilní řešení se nabízejí ve formě četnějších částečných úvazků, nestandardní pracovní doby či zaměstnanců efektivně pracujících z domova. Podobně i revize zákonů ohledně OSVČ a jejich zdanění by mohlo podpořit nárůst počtu živnostníků ${ }^{45}$ což by umožnilo př́ležitosti k reorganizaci domácího života rodiny tak, aby se do něj dalo zahrnout domácí vzdělávání. Čas vyhrazený pro domácí vzdělávání nemusí tvořit velkou část dne. Může být rozdělen do men-

42 Ve Spojených státech jsou nyní někteří rodiče přesvědčeni, že je čas začít s domácím vzděláváním: @ Emma Green, The Pandemic Has Parents Fleeing From Schools-Maybe Forever, The Atlantic, ze dne 13. 9. 2020, dostupné na: https://www.theatlantic.com/politics/ archive/2020/09/homschooling-boom-pandemic/616303/, citováno dne 30. 1. 2021.

43 Srov. Mary Kay CLARK, Catholic Home Schooling, Rockford (IL): Tan Books, 1993, s. 258-265.

44 ○) Zákon č. 285/2020 Sb. ze dne 10.6. 2020, dostupné na: https://www.epravo.cz/_dataPublic/sbirky/2020/sb0108-2020.pdf, citováno dne 1. 2. 2021, \$317a.

45 Současný český daňový systém ohledně OSVČ předpokládá, že se jedná o vedlejší př́ijem a osoba je již v zaměstnaneckém poměru. Poté, co se zaregistruje jako živnostník bez dalšího zaměstnání, musí platit značné sociální a zdravotní pojištění, a to i v případě, že má jen minimální nebo žádný prřijem ze své živnosti. Stát se živnostníkem bez garantovaného příjmu proto může být skutečným finančním rizikem. 
ších bloků ve vhodných denních dobách. Klíčovým faktorem je jasná organizace a pravidelné vyhodnocení efektivity využití času. Zatímco školy jsou v celkové organizaci času neefektivní, rodina se může rozhodnout, kdy se učit, pracovat, odpočívat, hrát si, být spolu a být každý sám se sebou. S dobrou vůlí a úsilím může rodina zjistit, co jí vyhovuje nejlépe. Učení také nemusí kopírovat zavedený model, kdy nejdříve 20-30 minut mluví učitel, a pak je podobný čas věnován práci žáka pod dohledem. Efektivní výukové vstupy přiměřené vzdělávacím potřebám a preferencím dítěte by často měly zabrat pouze několik minut. Aktivitu lze pravidelně kontrolovat, například každých deset minut. Přestávky a mnohé činnosti nepotřebují téměř žádný dohled. Hodina učení tudíž může vyžadovat pouze 10 minut času dospělého, což mu nechává větší část této hodiny $\mathrm{k}$ tomu, aby se věnoval svým pracovním aktivitám. Toto nelze zaručit za všech okolností, ale může se to dít často a se zkušenostmi se ještě zlepšovat. Důležité je to, aby práce i učení byly organizované tak, aby ani jedno z toho nebylo pravidelně omezováno.

Dalším velkým kamenem úrazu může být to, co se má vyučovat, což se týká jednak struktury a jednak používaných zdrojů. Součástí struktury je také obsah, zejména v českém systému, kde jsou děti hodnocené, takže znalost osnov je důležitá - je to však také užitečný nástroj jako měřítko a vodítko pro výuku. Dohlížející škola by ideálně měla nabízet určitou podporu na vyžádání, je však na odpovědnosti rodiče, aby rozvíjel své chápání toho, jak strukturovat výuku. Jednoduše následovat seznam požadavků je sice dostačující, mělo by však postupně docházet k rozvoji. Podpora by měla být vyhledávána a poskytnuta také v př́ípadě dětí s podprůměrnými nebo nadprůměrnými schopnostmi.

Co se zdrojů týče, v některých jazycích je k dispozici velký výběr knih, softwaru a dalších zdrojů, mnoho z nich on-line, často jsou tyto zdroje bezplatné. Např́klad některé kompletní kurikulum je možné vyučovat v angličtině bez jakýchkoliv nákladů - vyžaduje to pouze čas a trpělivost najít vhodné on-line zdroje. $\mathrm{V}$ češtině je výběr dostupných zdrojů více limitovaný, každým rokem se však zlepšuje. Dobře zvolená slova v on-line vyhledávači mohou vygenerovat velmi cenné a užitečné výsledky. Khan Academy i Duolingo poskytují obsah také v češtině. Khan Academy nabízí strukturovaný obsah pro mnoho předmětů, zatímco Duolingo může být bránou pro využíání jiných jazyků pro výukové zdroje. Knihkupectví také nabízejí řadu školních knih, zejména v zárí, aby podpořily učení dětí. Zdroje lze připravit i doma. Nejdůležitější však je zjistit, co je pro dítě nejvhodnější a jak se nejefektivněji učí.

Jak již bylo zmíněno, česká pravidla vyžadující dohled školy a ukládající přezkoušení mohou vést k tomu, že školy poskytují i určitou podporu. To může rozvíjet distanční výuku, jako ve škole Březová, jež nabízí výuková videa i možnost využít poradenství. Hodnocení probíhá prostřednictvím uploadu portfolia hotových prací - psaných, kreslených, projektů, videí atd. - a za normální situace také osobně každé pololetí na několika místech v republice. Na druhou stranu některé školy, které souhlasí, že budou dohlížet na domácí školáky, s tím mají relativně málo zkušeností a samy jsou bez podpory týkající se potřeb a způsobů domácí výuky; to může vést k čemukoliv od přehnaně kontrolovaných požadavků vést výuku podle konkrétních knih - takže z domácího vzdělávání se stane jen škola doma - až po pouze povrchní dohled, který by mohl potenciálně vést $k$ tomu, že se dítěti nedostane dostačujícího vzdělání ${ }^{46}$ Někteří vzdělavatelé vítají větší svobodu, ta však není valně nápomocná těm, kteří teprve začínají. $V$ ideálním případě by každý region disponoval alespoň jednou školou, která by se specializovala na supervizi domácích školáků, dle příkladu ZŠ Březová; nad těmito školami by pak mohl mít dohled odborník na vzdělávání, jenž by rozuměl důvodům i úskalím domácího vzdělávání, aby tato role nebyla vnímána zjednodušeně jako prvek státní kontroly.

46 Tuto obavu s autorem v konverzacích sdílelo několik zkušených vzdělavatelů. 
Sítě domácích vzdělavatelů mohou být velmi efektivním nástrojem pro rozvoj domácího vzdělávání. Začínajícím vzdělavatelům mohou doporučit vhodné dohlížející školy a nabídnout rady týkající se rozvržení času a nalézání a sdílení zdrojů. Zkušení domácí vzdělavatelé se mohou podělit o nápady a metody, inspirovat ostatní $k$ tomu, aby rozvíjeli svou sebedůvěru a efektivitu. Podobně tak geograficky utvořená sdružení mohou organizovat společné aktivity a výlety, sdílet informace jako třeba o specialistech ve sportu a hudbě nebo o rodilých mluvčích jazyků, které se děti učí. Také se mohou navzájem podílet na výuce dětí, využívat své různé specializace, uskutečňovat skupinové aktivity a projekty či se střídat $\mathrm{v}$ dohlí̌žní na skupinu dětí, aby umožnili druhým čas na práci apod. $V$ neposlední řadě - mít možnost hovořit s někým, kdo rozumí mé situaci, je také velmi důležité. Samozřejmě při narůstajícím počtu vzdělavatelů se může rozvíjet i vícero sítí, čímž se podpoří jejich diverzita - od specializací po osobnosti.

Na jiné úrovni, zejména povedou-li pandemická omezení ke zvýšenému zájmu o domácí vzdělávání v České republice, by se mohla rozvinout akademická angažovanost odborníků na vzdělávání, aby poskytovali podporu rostoucímu počtu vzdělavatelů. Výzkum a rozvoj nápadů je důležitý; některé země mají velké množství vzdělavatelů a podpưrné systémy, $\mathrm{z}$ nichž je možné se poučit, je však nezbytné je adaptovat na prostředí českého domácího vzdělávání. Odborníci z řad akademiků mohou poskytovat praktickou podporu budoucích i stávajících domácích vzdělavatelů v oblastech organizace, úvodního obsahu a rozvoje (částečně) zkušených vzdělavatelů: klíčovými oblastmi jsou práce $s$ časem, rozšiřování zdrojů, zvyšování efektivity v rámci osnov a zdrojů. Zatímco učitelé jsou vyškolováni a dál se průběžně vzdělávají, domácí vzdělavatelé tuto možnost nemají: i když někteří o to nebudou mít zájem, nabídka dobrovolné podpory by pomohla ostatním a povzbudila ty, kteří domácí vzdělávání zvažují. Podobně nápomocné by mohlo být i školení a podpora pro dohližející školy a jejich učitele, potenciálně vedoucí $\mathrm{k}$ vytvoření standardů specifické supervize a podpory. Myšlenka centra (angl. hub) domácího vzdělávání by mohla pomoci rozvoji místních sítí, podpořit více specializované školy, vytvořit užitečné zdroje a usnadnit pochopení osnov ze strany rodičů. Tak by mohlo docházet ke sdílení modelů výuky, od různých stylů až po denní či týdenní organizaci. Pokud by se toto uskutečnilo v akademickém prostředí, umožnilo by to rozvoj kvality vzdělávání při respektování faktu, že různí vzdělavatelé preferují různou míru podpory, př́íp. žádnou nevyžadují. Obecně řečeno, akademické prostředí by se mohlo stát velkou podporou pro domácí vzdělávání jak v rozvoji teorie, tak v praxi.

Konečně poslední důležitá otázka, jež může být v současné době v České republice problematická, spočívá v tom, že pokud se některé rodiny rozhodnou pro domácí vzdělávání po pandemických restrikcích, ř́zení této situace ohledně zákonných požadavků při hledání dohlížející školy a doporučení od pedagogického psychologa by mohlo všem velmi pomoct. Zvládnutím tohoto potenciálního problému by vzdělávací autority mohly minimalizovat či plně vyloučit možnou situaci, kdy by se školy nebo učitelé museli vypořádávat s rodiči a dětmi, kteří se již rozhodli školu nenavštěvovat, což by mohlo vést $\mathrm{k}$ narušení a nespokojenosti právě $\mathrm{v}$ době, kdy se školy snaží opět stabilizovat a vrátit do normálu. Možnými řešeními by mohla být databáze škol dohližejících na domácí školáky a prodloužení časové lhůty pro návštěvu pedagogicko-psychologické poradny, pokud již rodiče mají domluvený termín návštěvy.

S širší podporou ze strany státu formou větší flexibility v oblasti pracovních podmínek, výše zdanění, pravidel pro živnostníky, a dokonce zvýšenou organizací dohledu by se domácí vzdělávání mohlo stát reálnou možností pro více rodin, kdy některé děti mohou profitovat $\mathrm{z}$ vhodnější formy výuky. Se zvýšenou organizací a s rozvojem sítí se mohou domácí vzdělavatelé navzájem podporovat, sdílet nápady a zdroje a obdobně i čas. Může být nabídnuta akademická podpora pro nové 
i zkušené vzdělavatele a také pro dohlížející školy. Nárůst možností přinese více rodinám příležitost vzdělávat doma a spolu s tím i rozvoj kvality domácího vzdělávání, aby se zlepšilo vyučování a zvýšila míra štěstí a smysluplnosti v rodinném životě.

\section{Závěr}

Během pandemických omezení ve společnosti měly školní děti problémy s učením doma, podobně jako rodiče a učitelé, kteří se snažili poskytnout určitou úroveň kontinuálního vzdělávání. $\mathrm{Na}$ druhé straně domácí vzdělávání, které zůstalo prakticky nedotčené, je velmi malá ale narůstající možnost, kterou si vybírají rodiče rozhodnutí vzdělávat své děti doma. V České republice je domácí vzdělávání regulováno, vyžaduje, aby na takové děti dohlížela škola a hodnotila je. Pro někoho byla tato doba omezení příležitost vyzkoušet si vzdělávání doma, byt’ s většími zásahy do domácího prostředí ze strany školy než při běžném domácím vzdělávání. Děti, kterým učení doma prospělo, a rodiče, kteří tento způsob z rozličných důvodů upřednostňují a kteří se považují za schopné zajistit efektivní domácí vzdělávání, mohou nyní tuto možnost zvažovat.

Je mnoho překážek, které mohou zablokovat příležitosti k domácímu vzdělávání a zabránit realizaci domácího vzdělávání, nicméně nedávné změny v zákoníku práce některé problémy ulehčí. S dalšími změnami v legislativě, a s nastavením větší flexibility v zaměstnání budou uvolněna omezení, a tedy více rodičů bude mít možnost vzdělávat své děti doma. Pro nalezení řešení některých problémů je ale třeba překonat výzvy a někdy učinit oběti. Mezi řešeními může být např́íklad rozvoj zdrojů, podpora nových a stávajících rodin v domácím vzdělávání, rozvoj sítí - tyto tři oblasti by rozšírily škálu př́ležitostí ke zlepšení zkušeností s domácím vzděláváním i jeho efektivitu.

Akademická sféra může také sehrát důležitou roli: od poskytování podpory a poradenství pro začínající vzdělavatele až po vytvoření platformy pro zkušené, kde by mohli sdílet své nápady; přes nabídku podpory sítí a vytváření vzdělávacích center (hubů) až po rozvoj nápadů, jak by vzdělávací autority mohly více efektivně podporovat a dohlížet na domácí vzdělávání; stejně jako rozvíjet obecnou úroveň domácího vzdělávání vzdělavateli a pomáhat dohlížejícím školám stát se efektivnější a výkonnější nejen v hodnocení rozvoje dětí, ale také v nabízení způsobů podpory.

Skrze spolupráci všech zúčastněných - vzdělavatelů, dohlížejících škol, vzdělávacích autorit, akademických odborníků - může být domácí vzdělávání realizováno, podporováno a supervidováno $s$ vyššími standardy za současného respektování zdravé svobody v rámci této formy vzdělávání, a může se tedy pro některé rodiny stát reálně zvažovanou možností vycházející ze současných pandemických omezení.

\section{Kontakt}

\section{Stuart Nicolson, MA}

Jihočeská univerzita v Českých Budějovicích

Teologická fakulta

Katedra filozofie a religionistiky

Kněžská 8, 37001 České Budějovice

snicolson@tf.jcu.cz 